\title{
PLASTIC PRODUCTION AND WASTE GENERATION DURING THE COVID-19 PANDEMIC
}

\author{
Pranay Aggarwal \\ Delhi Public School, Mathura Road, New Delhi
}

DOI: 10.46609/IJSSER.2021.v06i06.013 URL: https://doi.org/10.46609/IJSSER.2021.v06i06.013

\begin{abstract}
The objective of this research is to underline the effect of covid 19 pandemic on plastic production and plastic waste generation.

A secondary research methodology has been used to provide insight to the situation of single use plastic production.

The paper will prove plastic production and consumption rose multifolds during the covid19 pandemic (in the year 2020) and to analyse its effect on climate.It will be comparing waste production before pandemic levels(before 2019) with post 2020 levels. This paper is meant to provide an insight to the largely ignored effect of the covid19 pandemic.

It will also suggest some changes and practices that can be opted by the government and the citizens and have also pointed to various ill effects of plastic pollution.
\end{abstract}

Keywords: Climate Conservation, Plastic, Pandemic, Pollution, Recycle, Single use Plastic

\section{Introduction}

The pandemic resulted in growth of single use plastic production and consumption as plastic became the single most barrier against this invisible enemy. The single use plastic consists of various medical equipment such as ppe kits, masks, synthetic gloves, face shield and other protective gears, medicine wrappers and vaccine syringes. In comparison to 2019, 2020 saw a surge in wastage of single use plastic where packaging accounted for $40 \%$, landfill accounted for more than $40 \%$ and is considered the most dominant disposable method of single use plastic.

Since the onset of the pandemic in December 2019, efforts have been made to understand the core structure of the sars-cov2 virus and studies showed that the virus could live on the surface 


\section{International Journal of Social Science and Economic Research}

Volume:06, Issue:06 "June 2021"

of plastic for almost 3 days. This meant that there was no scope of reusing medical protective gear which were made from plastic, and given the lethal nature of the virus, it was encouraged to use gears and change them after short intervals. Considering ppe kits and other gear are made of SUPs, we can only imagine how much more plastic was disposed off during this period of pandemic.

There have been reports from around the globe mentioning the improper disposal of these equipment. They have pointed out how plastic waste was dumped in landfills and rivers without any proper sterilization and without any consideration of recycling. All of this waste will eventually harm us in direct or indirect ways and cause adverse effects to the climate. To prevent this we need to draw some comparisons before we can understand the gravity of this situation. We need to look at the data of before the pandemic and after the pandemic so that we can comprehend how big these numbers are and how we can reduce them.

For the purpose of this report, I have used an approach of secondary research and have presented a critical analysis of various findings of other reports. Secondary research is a common approach to a systematic investigation in which the researcher depends only on existing data throughout the research process. It involves organizing, collating and analyzing the data samples provided to ensure valid research conclusions. Since I have used only data available online, I have made sure that I use data presented by reliable sources and media channels only.

This format of research is not only a cost \& time effective, gathering data from reliable sources ensures the authenticity of the data. Using this form of research also allows me an opportunity to identify any knowledge gaps which could be used to serve as the basis of further systematic investigation. 
International Journal of Social Science and Economic Research

ISSN: 2455-8834

Volume:06, Issue:06 "June 2021"

Worst Plastic Polluters in $\mathbf{2 0 2 0}$

Number of countries in which plastic waste

was found and pieces of waste recorded

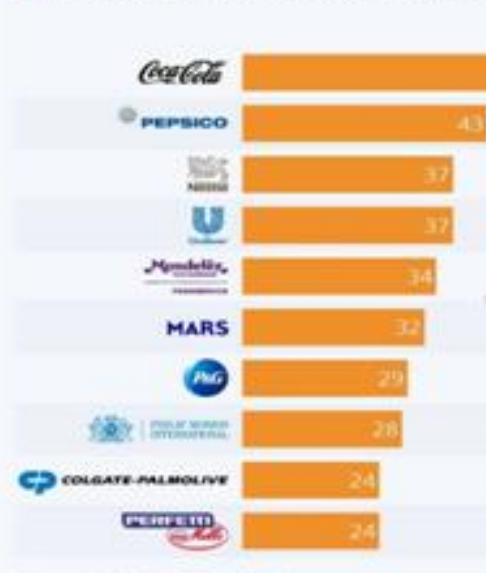

Source: Areak Free From Mlantic

(ㅇ)(1) $\odot$

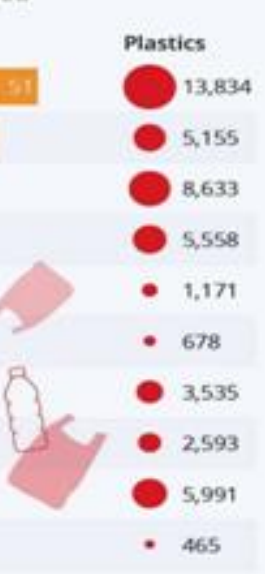

statista

\section{The Rivers Filling The Oceans} With Plastic

Global rivers ranked by tonnes of plastic load

carried into oceans each year"

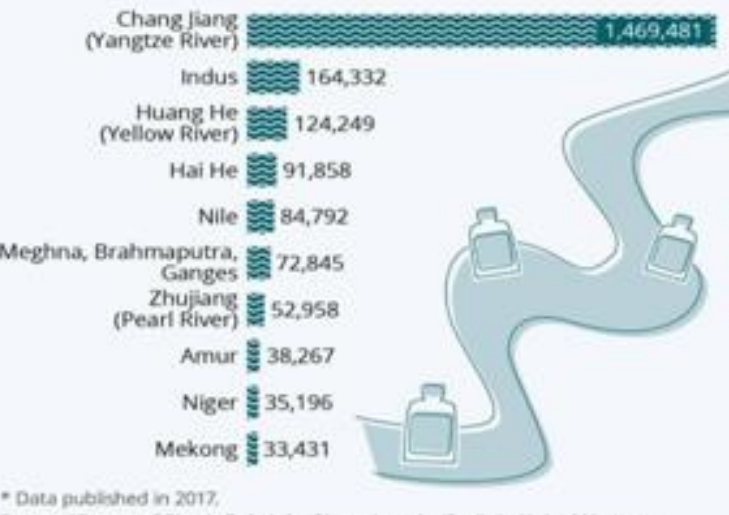

Source "Evport of Plastic Deboris by Fuvers into the Sear via United Nations () (1) $)$

\section{The Countries Polluting The Oceans The Most}

Annual metric tons of mismanaged plastic waste and total amount ending up in global waters

- Mismanaged plastic waste Plastic marine debris

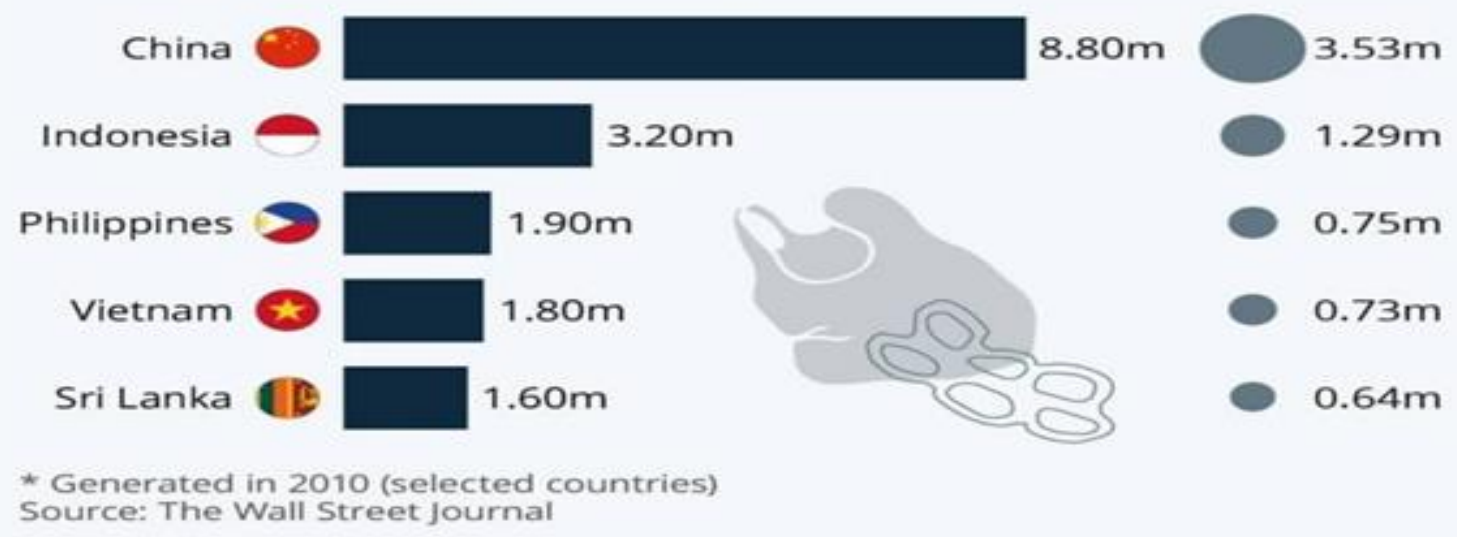

(c) $($ ) $\ominus$

statista 
International Journal of Social Science and Economic Research

ISSN: 2455-8834

Volume:06, Issue:06 "June 2021"

\section{Review of Literature}

Central Pollution Control Board, "Annual Report (2018-19) on Implementation of Plastic Waste Management Rules": This report was meant to be an induction of state wise distribution of different types of plastic production in India in the year 2018-2019. It provides empirical data of plastic production in different states and their types. It also suggests changes in the industry and harmful effects of the same.

Non Plastic Beach,"How Does Plastic Harm the Environment? (2019)": this report points out the dangers associated with improper plastic waste disposal. It suggests how plastic can cause harm to the environment with special emphasis on marine life. It suggests some ways through which we can handle this issue and overcome the problem of increased waste generation.

\section{Research Methodology}

For this research I will be using a secondary research approach and will be critically analysing various data available in different reports.

I have decided to use Data from source like: Central Pollution Control Board, Annual Report (2018-19,) on Implementation of Plastic Waste Management Rules, 2016,Report on managing plastic waste in India by Centre for Science and Environment and Performance plastic production volume in India FY 2015-20 by statista.com

Since the data presented in this report is open to all and readily available online, it may be noted that the information presented in this report might not bring any unique advantage to the reader. However it is solely my analysis and my interpretation that brings uniqueness to the information presented. Since data may be too generic, I had to identify relevant information necessary for this report and discard others. While I can ensure the information in this data is up to date, I still need to acknowledge the chances of newly updated data available in context to this paper.

\section{Research Objective}

The objective of this research paper is to help us identify an increment in the amount of plastic production and waste generated during the pandemic. Our research will also look into whether the government has been efficient in plastic disposal sustainably or not.

\section{Hypothesis}

Considering the overall plastic production,consumption and disposal has increased multifolds since the onset of lockdown,we can successfully hypothesize that the overall waste management 
of plastic products has worsened in the nation, which can be considered a direct implication of the pandemic.

\section{Data analysis}

\section{Plastic Waste Production before 2019}

As per a global material balance study on plastics, $79 \%$ of the world's plastic ends up as environmental waste. Only 9 percent of the total plastic waste is recycled. As stated by a CPCB (Central Pollution Control Board) report in 2018-19, the total annual plastic waste generation in India was at an enormous 1.6 million metric tonnes per year before 2019. Richer states like Goa and Delhi produce as much as 60 grams and 37 grams per capita per day respectively - against a national average of 8 grams per capita per day.

Graph 1: Top seven contributor states to total plastic waste generation in India - as of 2018-19, the country was producing 3.3 million metric tonnes a year

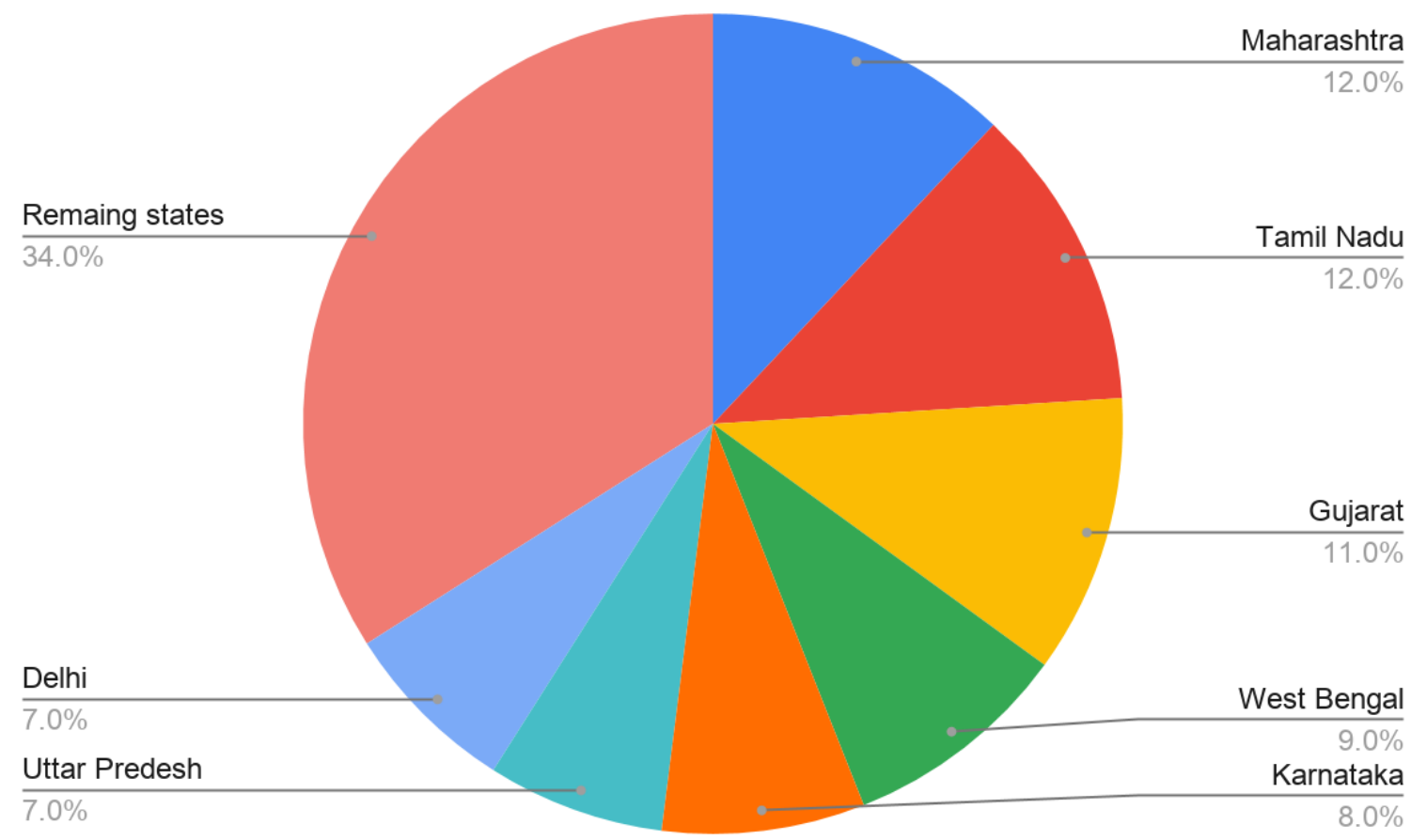

Source: Central Pollution Control Board, Annual Report (2018-19) on Implementation of Plastic Waste Management Rules, 2016 


\section{International Journal of Social Science and Economic Research}

ISSN: 2455-8834

Volume:06, Issue:06 "June 2021"

Table 1: Types of plastic generated and waste produced before 2019

\begin{tabular}{|c|c|c|c|c|}
\hline $\begin{array}{l}\text { Name of } \\
\text { plastic }\end{array}$ & Code & $\begin{array}{l}\text { Recycla } \\
\text { ble } \\
\text { or not }\end{array}$ & Few applications & Type of recycling \\
\hline $\begin{array}{l}\text { Polyethylene Terephthalate } \\
\text { (PET) }\end{array}$ & 1 & YES & $\begin{array}{l}\text { Water bottles, soft drink } \\
\text { bottles, food jars, films, sheets, } \\
\text { furniture, carpets, } \\
\text { paneling }\end{array}$ & $\begin{array}{l}\text { Converted back to polymer and used for } \\
\text { making apparel }\end{array}$ \\
\hline $\begin{array}{l}\text { High-density Polyethylene } \\
\text { (HDPE) }\end{array}$ & 2 & YES & $\begin{array}{l}\text { Milk pouches, bottles, carry } \\
\text { bags, recycling bins, base } \\
\text { cups }\end{array}$ & $\begin{array}{l}\text { Converted to pellets and used to } \\
\text { produce new HDPE }\end{array}$ \\
\hline Polyvinyl Chloride (PVC) & 3 & YES & $\begin{array}{l}\text { Pipes, hoses, sheets, wire } \\
\text { cable insulations, multilayer } \\
\text { tubes, window profile, } \\
\text { fencing, lawn chairs }\end{array}$ & $\begin{array}{l}\text { Pyrolysis, hydrolysis and heating are } \\
\text { used to convert PVC waste into calcium } \\
\text { chloride, hydrocarbon products and } \\
\text { heavy metals. These are used to } \\
\text { produce new PVC or as feed for other } \\
\text { manufacturing processes or as } \\
\text { fuel for energy recovery }\end{array}$ \\
\hline $\begin{array}{l}\text { Low-density Polyethylene } \\
\text { (LDPE) }\end{array}$ & 4 & YES & $\begin{array}{l}\text { Plastic bags, various } \\
\text { containers, dispensing bottles, } \\
\text { wash bottles }\end{array}$ & $\begin{array}{l}\text { Converted to pellets and used to } \\
\text { produce new LDPE }\end{array}$ \\
\hline Polypropylene (PP) & 5 & YES & $\begin{array}{l}\text { Disposable cups, bottle caps, } \\
\text { straws, auto parts, industrial } \\
\text { fibres }\end{array}$ & $\begin{array}{l}\text { Converted to pellets and used to } \\
\text { produce new PP }\end{array}$ \\
\hline Polystyrene (PS) & 6 & NO & $\begin{array}{l}\text { Disposable cups, glasses, } \\
\text { plates, spoons, trays, CD } \\
\text { covers, cassette } \\
\text { boxes, foams }\end{array}$ & Not recyclable \\
\hline Others $(\mathrm{O})$ & 7 & NO & $\begin{array}{l}\text { Thermoset plastics, multilayer } \\
\text { and laminates, nylon SMC, } \\
\text { FRP, CD,melamine plates, } \\
\text { helmets, shoe soles }\end{array}$ & $\begin{array}{l}\text { Not recyclable - however, multilayer } \\
\text { packaging could be crushed and turned } \\
\text { into sheets and boards for roofing, } \\
\text { using adhesives }\end{array}$ \\
\hline
\end{tabular}


International Journal of Social Science and Economic Research

ISSN: 2455-8834

Volume:06, Issue:06 "June 2021"

Sources: Columns 1 to 4 is sourced from the CPCB report titled Consolidated Guidelines for Segregation, Collection and Disposal of Plastic Waste; column 5 are based on data on recycling done in India (collated by CSE from various sources)

\section{Single use plastic}

There has been no official definition of single use plastic from the government.

But the prime minister Narendra Modi has defined them as plastics which are used only once and then discarded (he said this in his address on October 2, 2019). At times, it is misunderstood to mean only polythene bags.

As per an UN definition, any plastic that is made from polymers of HDPE, LDPE, PET, PS, PP or EPS is single-use plastics. The definition of the government of Australia says that single-use plastic includes shopping bags, cups, straws and packaging — basically anything that is intended only to be used once and then discarded. The IEEP (Institute for European Environment Policy) and the European Commission definition says single use plastics can include any disposable plastic item which is designed to be used only once.

\section{From 2020 onwards}

After the onset of pandemic, the single use plastic became more diverse incorporating the following as well: ppe kits, synthetic masks, face shields, plastic gloves, medical equipment, disposable cutlery for the infected patients, to-go delivery bags and packaging, medicine wrappers, syringes etc.

It was advised to discard the above mentioned products(specifically ppe kits, mask, face shields, synthetic gloves, cutlery) after single use. During peak seasons of infections-particularly summers of 2020 and 2021, people became more cautious and started discarding these on a daily basis. Medical personnel were discarding PPE kits by the hour on a daily basis. All this waste generated was not discarded separately on a larger scale.

Along with annual generation of plastic waste, the covid-19 pandemic caused added waste generation. The lockdown saw an increase in home deliveries of food and other essential products. E-commerce saw an increase in sales which further increased the waste produced due to packaging materials.

Although, the annual plastic production was just 821 thousand metric tons.

\section{Comparison}




\section{International Journal of Social Science and Economic Research}

ISSN: $2455-8834$

Volume:06, Issue:06 "June 2021"

As the data suggests, there is no denying that overall plastic production decreased drastically in the year 2020,(from 1589 thousand tons in 2019 to 821 thousand tons in 2020),but the overall plastic waste generation increased in the year 2020.

Plastic was being produced for long term use in the year 2019 along with the single use plastic. Heavy (strong polymer) plastic was being largely produced in 2019 , but due to nationwide lockdowns along with local restrictions, many manufacturing units shut their factories entirely for the year 2020 resulting in overall low production of plastic. It is estimated, despite many advantages favoring the plastic industry in the country, these units had to let go as much as $30 \%$ of their employees due to this lockdown in spite of having increased demands.

Of the plastic produced in 2020, most of it was used as single use and was used to combat the pandemic. Hence, the waste generation also rose. The country relied on its existing stocks of heavy plastic goods for most of the year, but of the decreased production of plastic, most of it was discarded without proper management.

\section{Discussion}

Since cumulative surveys couldn't be done in the year 2020-21, our data is limited for these years. But from what is provided, we can reasonably conclude plastic generation reduced in the year 2020 but single use plastic production rose during the same period. Also disposal of single use plastic also rose given the demand for goods in the medical sector rose and the management of this bio-waste reduced due the fear of catching the covid disease.

At the UNEA held in Nairobi, Kenya, between March 11 and 15, 2019, India piloted a resolution on phasing out single-use plastic by 2022, a deadline later updated to 2025. A majority of member countries opted to go in for a less ambitious "reduction by 2030". The UNEA is the world's highest-level environmental forum with 170 member states. But considering the onset of the global pandemic, it seems unlikely that India might be able to meet the deadline of 2025 as well.

Plastic production has increased twenty-fold since 1964. Globally, approximately 311 million tonnes of plastics were produced in 2014, expected to double in about 20 year time and possibly quadruple by 2050. International Energy Agency World Energy Outlook in 2015 estimated that, the largest application, plastic packaging (26\% of the overall volume), is envisaged to have continuous strong growth, which might double within 15 years, with a possibility of fourfold increase by 2050, to about 318 million tonnes yearly, which is higher than the whole plastic industry today. 


\section{International Journal of Social Science and Economic Research}

ISSN: $2455-8834$

Volume:06, Issue:06 "June 2021"

Plastic production and waste generation is expected to rise only after the pandemic and this has serious impact on climate pollution and climate change. It takes at least 400 years for a bag to biodegrade which has the following effects:

- Natural Environment estimates that approximately 100,000 sea turtles and other marine animals die every year because they get strangled in bags or mistake them for food.

- In Australia, 50 million garbage bags end up as litter yearly, and the "plastic soup" patch in the Pacific Ocean (twice the size of the continental United States) is roughly $80 \%$ of the ocean.

Like with plastic bags, plastic water bottles were until recently considered an essential part of everyday life, whilst being thrown away at will. This leads to some of the following effects:

- Overflow at landfills, requiring high amounts of fossil fuel for production

- Covering the ocean surface leading to the destruction of habits and wildlife

- Importing waters from overseas requires trucks for transportation and delivery, which has a large environmental impact.

Not only these, the surge in plastic production due to the pandemic also affects the environment in a similar manner. The major concern with plastic is that it takes too long to decompose and there is no economical method to fasten this process. Recycling can be done but it is too costly as compared to producing new plastic. Governments should increase subsidies in the recycling sector to make this process more cost effective and efficient. An absolute ban on SUPs is almost impossible but the government can make sure that wastage of SUPs is prevented wherever possible. Medical SUPs such as masks and ppe kits should be sterilized and recycled so that they don't end up in landfills. Innovative methods should be made a priority when handling plastic waste and reduce it significantly in the upcoming years. Citizens should look into alternatives for plastic suggested by the government and focus more on reuse than recycle. They need to be made aware of the adverse effects of plastic by the government bodies and make sure they are well educated on the subject.

Remember citizens are only as well responsible as the government.

\section{Results}

Plastic pollution increased multifolds during this pandemic since single use plastic was used to provide various amenities. Waste management of this disposed off plastic hasn't been done 


\section{International Journal of Social Science and Economic Research}

ISSN: $2455-8834$

Volume:06, Issue:06 "June 2021"

efficiently and the amount of plastic recycled is very low. Production of plastic declined from 1589 thousand tons in 2019 to 821 thousand tons in 2020 but still due to SUPs, waste generation increased due to the pandemic.

If plastic waste generation doesn't decrease, there will be severe harmful effects to us. Both economically and morally, plastic waste recycling is a better alternative. If plastic is not treated correctly before disposal, it will end up either in landfills or oceans from where marine life or other animals may consume them resulting in their death. Not only does that harm natural food chains, biodiversity contamination can lead to extinction of entire species of organisms thus affecting humans directly or indirectly.

Most of the beaches worldwide suffer from littering of single-use packaging of food and beverages, leading to loss in livelihoods when tourism is affected. In California, more than half a billion dollars are spent annually to clean beachfronts for tourism. Countries in the Asia-Pacific region report losses of $\$ 622$ million a year due to littered beaches, while fishing industries lose $\$ 364$ million per year, and the shipping industries lose \$279 million each year. So the total cost of marine pollution in this region alone is $\$ 1.26$ billion per year.

Thus it is very important to recycle and reuse plastic waste and reduce production of new plastic especially single use plastic.

\section{Conclusion}

This paper concludes that although plastic production saw a decrease in 2020 due to the pandemic lockdown, the SUP production still saw an increase to meet the demand from the medical sector and to produce personal protective gear.Overall plastic discarded was more for the year 2020 due to various factors. Recycling and waste management hasn't been done efficiently and all climate conservation norms were ignored while dealing with the pandemic. The long term effects have been discussed and some major steps that can be taken by both citizens and the government for reduction of plastic waste has been highlighted in the paper.

\section{ACKNOWLEDGEMENT}

I would like to express my sincere gratitude and indebtedness to Ms. Tabassum for her enlightening lectures. I would also like to express my sincere gratitude to our teaching staff for guiding me on the path towards gaining knowledge.

The material borrowed from other sources and incorporated in the thesis has been duly acknowledged. 
International Journal of Social Science and Economic Research

ISSN: 2455-8834

Volume:06, Issue:06 "June 2021"

I understand that I could be held responsible and accountable for plagiarism, if any, detected later on.

\section{References}

Ananda Banarjee, Bloomberg Quint,"India Is Generating Much More Plastic Waste Than It Reports. Here's Why",(2019) Available at; (https://www.bloombergquint.com/global-economics/india-is-generating-much-more-plasticwaste-than-it-reports-heres-why) (Accessed on 1st May 2021)

Central Pollution Control Board, "Annual Report (2018-19,p10) on Implementation of Plastic Waste Management Rules"; Available at (https://www.cseindia.org/content/downloadreports/10352), (Accessed on 30th april,2021)

Central Pollution Control Board, “Annual Report (2018-19,p15) on Implementation of Plastic Waste Management Rules"; Available at (https://www.cseindia.org/content/downloadreports/10352), (Accessed on 30th april,2021)

Centre for Science and Environment,"Managing plastic waste in India(2020)";Available at (https://www.cseindia.org/plastic-waste-is-india-s-and-the-world-s-most-formidableenvironmental-challenge-10375), (Accessed on 27th April, 2021)

Formplus blog "What is secondary research?" (2020), Available at; (https://www.formpl.us/blog/secondary-research), (Accessed on 25th April,2021)

Justine Ammendolia, Jacquelyn Saturno, Amy L. Brooks, Shoshanah Jacobs,Jenna R. Jambeck,"An emerging source of plastic pollution: Environmental presence of plastic personal protective equipment (PPE) debris related to COVID-19 in a metropolitan city(2020)", Available at (https://www.sciencedirect.com/science/article/pii/S0269749120368494),(accessed on 25th April)

Non Plastic Beach,"How Does Plastic Harm the Environment? (2019)",Available at, (https://nonplasticbeach.com/blogs/latest/how-does-plastic-harm-the-environment) (Accessed on 5th May 2021)

Okunola A Alabi, Kehinde I Ologbonjaye, Oluwaseun Awosolu and Olufiropo E Alalade,"Public and Environmental Health Effects of Plastic Wastes Disposal: A Review" ,Available at, (https://clinmedjournals.org/articles/ijtra/international-journal-of-toxicology-and-riskassessment-ijtra-5-021.php?jid=ijtra) (Accessed on 5th May 2021) 
International Journal of Social Science and Economic Research

ISSN: 2455-8834

Volume:06, Issue:06 "June 2021"

Statist,"Performance plastic production volume in India FY 2015-20" Available at (https://www.statista.com/statistics/1067510/india-performance-plastics-production-

volume/\#: :text=Performance \%20plastics\%20production\%20volume\%20in\%20India\%20FY\%2 02015\%2D2020\&text $=$ In\%20fiscal\%20year\%202019\%2C\%20the, around $\% 201.6 \% 20$ million $\% 2$ 0metric\%20tons.), (Accessed on 1st May,2021)

Yuan Chen, Abhishek Kumar Awasthi, Fan Wei, Quanyin Tan, Jinhui Li, "Single-use plastics: Production, usage, disposal, and adverse impacts,Science of The Total Environment, Volume 752,2021",Available at

(https://www.sciencedirect.com/science/article/pii/S0048969720353018),(Accessed on 25th April, 2021) 